\title{
Seeing the EU from Outside its Borders: \\ Changing Images of Europe
}

\author{
Natalia Chaban ${ }^{1}$ \\ Martin Holland ${ }^{1}$ \\ National Centre for Research on Europe, \\ University of Canterbury \\ Kirkwood Village KD04, \\ Christchurch, New Zealand \\ E-mail: natalia.chaban@canterbury.ac.nz \\ E-mail: martin.holland@canterbury.ac.nz
}

\begin{abstract}
This paper outlines the importance of the studies of EU external perceptions in the Asia-Pacific region in the times of global multipolar redesign and an ongoing eurozone sovereign debt crisis. It links understanding of the concepts of EU external images and EU international 'branding' to the conduct of the EU's foreign policy. The paper also details the methodology of the transnational comparative research project 'The EU in the Eyes of Asia Pacific' which informs all contributions to this Issue. The paper then presents those contributions which explore EU external perceptions in nine Asia-Pacific locations, members of the Asia-Europe Meeting (ASEM) process: China, Japan, South Korea, India, Singapore, Thailand, Australia, New Zealand, and Russia.
\end{abstract}

Keywords: Asia-Pacific, the European Union, EU external perceptions

The changing architecture of the world follows a multi-polar blueprint - a redesign characterised by power shifts from the West to the East and South (Renard \& Struye de Swielande, 2011, p. 4) and by increased interdependence and interconnectedness between the 'poles' of power (Islam, 2012). With the "beating heart of international affairs [...] moving from the Atlantic to the Pacific" (Renard \& Biscop, 2012, xv), the Asia-Pacific region is in the limelight of global attention. The area hosts a number of 'emerging' powers boasting dynamic economies, vibrant demographics and growing ambitions as 'heavyweights' in the global economy. Yet, economics is not the only area where

1 Guest editors of December 2013 issue. 
hegemony of the West is challenged - the 'emerging' powers are consolidating "their political weight-notably in international fora-and their cultural influence - in the fields of science, education or culture" (Renard \& Biscop, $\mathrm{xv}$ ). Asia's rise in particular is understood through financial, monetary, scientific and military dimensions in addition to just economic ones (Renard \& Struye de Swielande, 2011, p. 3).

The EU's response to this changing world order was the 2009 Lisbon Treaty that facilitated the reassessment of the Union's relations with external world, initiated new priorities and directions in EU foreign policy, and voiced the EU's ambition to retain and reinforce its status as a major global player. Regarding significant milestones in the EU's interactions with Asia and Pacific, the recently established European External Action Service (EEAS) have noticeably been investing time and efforts in maintaining comprehensive dialogues with three strategic partners (China, India, and Japan) as well as negotiating a series of Free Trade Agreements (FTAs), completed with South Korea, and in progress with Japan, India, Singapore, and Malaysia (EEAS). Interregional ties have also had a role to play, including relations with regional integrationist bodies such as the Association of South-East Asia Nations (ASEAN), the ASEAN Regional Forum (ARF), the South Asian Association for Regional Cooperation (SAARC), the Pacific Island Forum (PIF), and the Asia-Europe Meeting (ASEM). Relevant literature suggests that the foci and comprehensive agenda of EU-Asia relations over the last two decades represent a significant development in the dialogue (Tsuruoka, 2011, p. 95). While the accent has been traditionally on economic interactions, Brussels has attempted in parallel to stress its political and security personality in Asia (Tsuruoka, 2011). However, more critical observers have queried whether or not the EU is able and/or prepared to deal with emerging Asia. Some experts fear that an increasingly "inward-looking Europe" lacks "a sophisticated and cogent strategy" towards a rising Asia (Renard \& Struye de Swielande, 2011, p. 4), resulting in a "weak political imprint in Asia" (Islam, 2010). And even Tsuruoka accepts that the EU's achievements in highlighting its political and security profiles in Asia have been "lacklustre at best".

This particular issue of the Baltic Journal of European Studies (BJES) contributes to this debate and presents the latest empirically informed insights into how key Asia-Pacific players have imagined and perceived the EU before and after Lisbon-as well as before and after the outbreak of the sovereign euro debt crisis. This thematic focus continues the BJES's ongoing interest in research of the 'rising Asia' and in its relations with the EU and wider Europe (Kirch \& Tuisk, 2013). A further motivation drew on the need to assess any changes in EU visibility and impact during the EEAS formative years in 
comparison with the EU profile of the previous decade. Critically, it is important to determine whether or not the latest economic challenges in Europe have led to the deterioration of the EU's external images. Image is defined here as "the total cognitive, affective, and evaluative structures of the behaviour unit, or its internal view of itself and its universe" (Boulding, 1969, p. 423). The images thus are believed to "provide $[. .$.$] the key to interpreting the action"$ (Castano et al., 2003, p. 45) - "the mutual images held by actors affect their mutual expectations about Other's behavior and guide the interpretations of the Other's actions" (Castano et al., 2003, p. 449). Research into the images and branding of the main international players in an increasingly multi-polar world is in high demand. Yet, although the EU is a leading global actor, limited data is available on how third countries perceive the EU in this role and no comparative studies have explicitly examined the changes to the EU's external image over time. Consequently, the study of the EU's international actor image in 'third' countries remains a challenging and still under-researched area in EU identity scholarship. Third party understandings about the EU and its roles form a part of the inter-subjective international structures that help to shape the practices of both Member States and the EU as such (Bretherton \& Vogler, 1999, pp. 29, 33).

Contributors to this issue discuss images and perceptions of the EU originating from ten countries: Japan, South Korea, China, India, Singapore, Malaysia, Thailand, Australia, New Zealand, and Russian Federation. With the possible exception of New Zealand, these ten could be also described as Asia-Pacific 'giants' - with growing economies, increasing political weight in the region, and enhanced international reputations in various multilateral fora (including G-20, WTO, Climate Change Conventions, etc.). All ten are also 'Asian' ASEM members. ASEM, an intergovernmental organisation which brings together Asian and European governments ${ }^{2}$ in a unique informal multilateral dialogue on political, security and the economy issues as well as education and culture, is used in this Issue as an organising principle.

This volume of $B J E S$ represents the latest phase of a longitudinal research agenda concerning the study of EU external perceptions in the Asia Pacific that has been conducted by the National Centre for Research on Europe (NCRE), New

In 2012, ASEM included 27 European Union Member States, 18 Asian states, the European Commission, and the ASEAN Secretariat. While the scholars are criticising the process as a "talk shop" and "bling-bling" event which lacks executive mechanisms and a clear international identity (an international body that oscillates between pure "region-to-region" to pure "state-to-state" interpretations), this Issue treats ASEM as a unique form of international dialogue which brings Asia and Europe, its states and supranational organisations, a step closer to each other, irrespective of the concrete outcomes of the process or modes of interaction. 
Zealand, over the last decade (Holland et al., 2007; Chaban \& Holland, 2008; Chaban et al., 2009; Holland \& Chaban, 2010; Chaban \& Holland, 2013; for more publications see www.euperceptions.canterbury.ac.nz). All contributors to this issue of BJES use the datasets collected from this transnational comparative project 'The EU in the Eyes of Asia Pacific' (2002-ongoing) which has involved leading universities in Asia-Pacific, ${ }^{3}$ spread across 21 locations since its inception. ${ }^{4}$ The project's latest stage $(2010-2012)$ was supported by the Jean Monnet Programme of Life Long Learning initiative of the Directorate General for Education and Culture of the European Commission, and Asia Europe Foundation (ASEF), Singapore, ASEM's only institution, with the mandate to promote mutual understanding between Asia and Europe. This latest stage of the project has provided a unique and immediate mechanism to assess the impact of the Lisbon Treaty innovations. By late 2010 the EEAS had become operational: the original research question was to trace the imagery of the post-Lisbon EU in its dialogue with Asia-Pacific in the EEAS's formative years, including the impact of the first High Representative for Foreign and Security Policy (HR FASP). The timing of the project was fortuitous in that it coincided with the eurozone sovereign debt crisis, and this dramatic development added a twist to the original research question which now also aimed to identify how the debt crisis influenced or damaged the image of the EU in the Asia-Pacific region.

The data used to answer these questions came from a systematic comparative study of EU external perceptions incorporating three elements: (1) the study of EU imagery in the national news media (press and television), (2) insights into the public opinion, and (3) assessment of the views of the national decisionand policy-makers. This research design has become internationally recognised and replicated by a growing number of "EU external perceptions" projects worldwide. The first phase of the project — daily monitoring of the three leading papers (a prestigious broadsheet with the highest national circulation, the most popular business daily and for comparative purposes an English-language daily) and the most watched prime-time television newscast for six months (JanuaryJune 2011) - resulted in an impressive sample of 7,963 news items (see Table 1).

3 Monash University and University of Melbourne, Australia; Jawaharlal Nehru University, India; Waseda University and Keio University, Japan; Fudan University and Tshinghua University, China; Hong Kong Baptist University; University of Macau; National University of Singapore; Korea University; Chulalongkorn University, Thailand; University of Malaya; Ateneo de Manila University, the Philippines; Universitas Indonesia; Vietnam National University.

4 Japan, South Korea, mainland China, SAR Hong Kong, SAR Macau, Singapore, Thailand, Malaysia, Indonesia, Vietnam, the Philippines, India, Australia, New Zealand, Russia, Fiji, Papua New Guinea, Samoa, three Solomon Islands, the Cook Islands. 
Table 1. List of media outlets monitored in the project

\begin{tabular}{|l|l|l|l|l|}
\hline & $\begin{array}{l}\text { Popular } \\
\text { daily }\end{array}$ & $\begin{array}{l}\text { Business } \\
\text { daily }\end{array}$ & $\begin{array}{l}\text { English- } \\
\text { language daily }\end{array}$ & TV news \\
\hline China & $\begin{array}{l}\text { People's } \\
\text { Daily }\end{array}$ & $\begin{array}{l}\text { International } \\
\text { Finance News }\end{array}$ & China Daily & CTV1 \\
\hline $\begin{array}{l}\text { South } \\
\text { Korea }\end{array}$ & Chosun & $\begin{array}{l}\text { Maeil } \\
\text { Business }\end{array}$ & Korea Herald & KBS News 9 \\
\hline Japan & Yomiuri & Nikkei & Japan Times & News Watch 9 \\
\hline India & $\begin{array}{l}\text { Dainik } \\
\text { Jagran }\end{array}$ & $\begin{array}{l}\text { The Economic } \\
\text { Times }\end{array}$ & $\begin{array}{l}\text { The Times of } \\
\text { India }\end{array}$ & $\begin{array}{l}\text { Doordarshan } \\
\text { News }\end{array}$ \\
\hline Singapore & $\begin{array}{l}\text { Lianhe } \\
\text { Zaobao }\end{array}$ & $\begin{array}{l}\text { The Business } \\
\text { Times }\end{array}$ & $\begin{array}{l}\text { The Straits } \\
\text { Times }\end{array}$ & $\begin{array}{l}\text { Channel 8 at } \\
\text { 10pm }\end{array}$ \\
\hline Malaysia & $\begin{array}{l}\text { Utusan } \\
\text { Malaysia }\end{array}$ & $\begin{array}{l}\text { The Edge } \\
\text { Financial Daily }\end{array}$ & The STAR & $\begin{array}{l}\text { Buletin Utama } \\
\text { (TV3) }\end{array}$ \\
\hline Thailand & Thai Rath & Manager Daily & Bangkok Post & IT V \\
\hline Australia & $\begin{array}{l}\text { The Herald- } \\
\text { Sun }\end{array}$ & $\begin{array}{l}\text { The Australian } \\
\text { Financial } \\
\text { Review }\end{array}$ & The Australian & $\begin{array}{l}\text { ABC News at } \\
7 p m\end{array}$ \\
\hline $\begin{array}{l}\text { New } \\
\text { Zealand }\end{array}$ & $\begin{array}{l}\text { The NZ } \\
\text { Herald }\end{array}$ & $\begin{array}{l}\text { The National } \\
\text { Business } \\
\text { Review }\end{array}$ & The Press & $\begin{array}{l}\text { One News at } \\
\text { 6pm }\end{array}$ \\
\hline Russia & $\begin{array}{l}\text { Russian } \\
\text { Newspaper }\end{array}$ & Vedomosti & $\begin{array}{l}\text { The Moscow } \\
\text { Times }\end{array}$ & $\begin{array}{l}\text { Channel 1 } \\
\text { Russia at 9pm }\end{array}$ \\
\hline
\end{tabular}

Concepts under observation included the EU itself, as well as its key institutions (European Commission, European Parliament, European Central Bank and European Court of Justice) and the eurozone. The public opinion phase involved surveying 10,000 respondents across the ten countries $(1,000$ respondents in each location, margin of error \pm 2.5 ). The online questionnaire was administered by the professional social research group TNS London and the sample was stratified according to gender, age and ethnicity. The final phase - the semi-structured faceto-face interviews with the national stakeholders - resulted in 425 interviews with the representatives of the four 'elite' cohorts: politicians, business people, newsmakers and civil society leaders. Transcribed verbatim and translated into English, the results of the elite and public opinion surveys were analysed using qualitative and quantitative methods. A mixed approach was also used to analyse the media data. All members of the research team (totaling more than a dozen) were formally trained in the methods of data collection and analysis, and participated in a number of research workshops and presentations of findings to academics and diplomatic practitioners from the EU and Asia-Pacific. 
This extremely rich dataset allowed our contributors to elaborate case studies involving comparative thematic findings across different locations, as well as specific analyses of single countries. While the 2011-2012 datasets were used as the primary source of empiricism to substantiate arguments, contributors were also able to draw on datasets from the earlier stages of the 'The EU in the Eyes of Asia Pacific' (2002-2010) research project, thereby facilitating a longitudinal perspective of EU imagery in the region. This volume thus presents a unique insight into the patterns of EU visibility that were evident in the AsiaPacific region under both the Amsterdam and Lisbon provisions, and before and after the outbreak of the eurozone sovereign debt crisis. The intricate matrix of comparisons - across themes, time and space - allowed this issue to consider the EU's external imagery from a dynamic and multifaceted perspective-a rare quality in the field dominated by 'snap-shot' country-specific studies.

This issue of BJES is organised 'geographically', yet common themes emerge in every 'regional' section. The first section features three papers that explore North East Asian perceptions of the EU under the common theme of the perception of the EU as a leading economic player. Li Zhang and Suet-yi Lai's article "Challenging the EU's economic roles? The impact of the sovereign eurozone debt crisis on EU images in China" examines how China's images of the EU as an economic power have changed over time (reflecting the eurozone debt crisis) through the prism of the images of the EU represented in the news media and those held among the national elites). Intriguingly, the conclusion of this paper is that despite the ongoing crisis, media and elite discourses of the 'emerging power' of China registered only a slight deterioration in the evaluation and meaning given to the EU as a "great" economic power. The paper discusses a number of factors which were thought to be influential in the formation of EU perceptions in China. The analysis in Sung-Won Yoon's paper "Is FTA for 'Up Closer and Personal'?" contrasts media coverage with the public's views towards the EU in South Korea - before and after - the completion of EU-Korea FTA negotiations. Revisiting findings from several previous waves of "EU external perceptions" projects in Korea (2006-2012), the paper confirms that over the years, the EU has typically been seen in Korea through a magnifying glass of economic perceptions (both by the newsmakers and the general public), and the reportage of the FTA negotiations has further solidified this image. This led to a paradoxical situationwhile the EU's overall visibility in South Korea was enhanced over the years, this has not necessarily led to a deeper understanding of the EU as a complex global actor. The paper by Paul Bacon and Emi Kato, "Potential still untapped: perceptions of the European Union as an economic and normative power in Japan" echoes the Korean study by focusing on the perceptions towards the EU in the 
ongoing EU-Japan FTA/EPA negotiations. Comparing the data from media and elite elements of the study, this paper also explores EU imagery as a normative and diplomatic power. Encouragingly for the newly established EEAS, and despite the critical economic circumstances in Europe, the Japanese case study revealed positive profiles towards the EU as a political actor, supported by visible neutralto-positive evaluations assigned by the Japanese media and elites to the activities of the newly appointed leader of the EEAS, HR FASP Catherine Ashton.

Political and normative themes were particularly visible in the second section of this issue which featured two case studies from South and South East Asia. The paper written by Loke Hoe Yeong and Yeo Lay Hwee, "Who acts for the EU before and after the Lisbon Treaty?", investigated the visibility of EU's external action (which the provisions of the Lisbon Treaty sought to address) in two South-East Asian countries-Singapore and Thailand. Using news media data before from 2006 and 2011, a comparison of the images and patterns of visibility of the leading EU actors in these two countries is presented in the context of the EEAS's outreach to South East Asia. The study demonstrates that the visibility of Catherine Ashton was modest in contrast to the leaders of certain individual EU Member States and the head of the ECB. While this could be explained by the fact that the ongoing crisis could have marginalised the standing of the High Representative (who was not mandated to oversee the economic and financial aspects of the Union), the higher visibility of Ashton in the Chinese and Japanese media suggests that this low profile may be more a reflection of her showing minimal personal interest to South East Asia as evidenced by her rare visits to the region. In their paper "Indian Elites and the EU as a normative power", Rajendra Jain and Shreya Pandey discuss the evolution of the concept of normative power in general and the EU's normative identity in particular in the eyes of Indian decision-makers drawing on interviews conducted in 2011-2012. The findings point to the normative disconnect in worldviews, mindsets and practical agendas between India and the EU and the paper concludes that this situation makes it difficult to transform shared values into coordinated policies.

The third section features case studies of EU external perceptions drawn from the three newest ASEM members-Australia, New Zealand, and Russia-who originally joined the process under the 'third group' category but have been subsequently upgraded to full 'Asian' members. Eva Polonska-Kimunguyi and Patrick Kimunguyi's paper "Communicating the European Union to Australia: The EU information strategy and its reception Down Under" reviews strategies used by the EU to 'communicate Europe' to its citizens and to the wider world after Lisbon. This study considers the application of these strategies to Australia and against this context; it builds a background to the analysis of EU images 
held in the Australian media, general public and among the newsmakers. The images are compared across time and the findings are discussed in relation to their application to EU public diplomacy initiatives in Australia. Serena Kelly's "New Zealand's elite perceptions on the EU: a longitudinal analysis" paper traces the changes in EU perceptions held among New Zealand 'elites' before and after the Lisbon and the eurozone debt crisis. The study assesses the views of the EU as a great power and an international leader, as well as evaluates the perceived importance of the EU to New Zealand in comparison to other regions. These New Zealand findings are consistent with a 'capability-expectations gap' approach. The penultimate paper "Russian vision of the EU in its interactions with the neighbourhood" by Olga Gulyaeva compares images of the EU across the three discourses - media, public, and elites - exploring two case studies: perceptions of the EU acting in the shared Russia neighborhood (former Soviet titular republics) and in the EU's neighborhood distant from Russia (Middle East). Events of the "Arab Spring" and EU's ongoing enlargement to the East are the two developments that contextualise this investigation: the analysis concludes that the images of the Other (the EU for Russia) actually say more about the Self (Russia) and betray its own ambivalent self-visions in the changing world order. This issue of BJES concludes with a commentary written by a political practitioner, Ambassador Dominique Girard, the former Head of ASEF, who reflects on the role and importance of mutual perceptions in the dialogues between Europe and Asia. It is now commonly asserted that Asia is rising, and is "increasingly confident, in a good shape and knows what it wants" (Islam, 2012). In contrast, the conclusions that can be drawn from an analysis of the EU's images and perceptions are more mixed, conveying both positive and negative messages for EU policy-makers and citizens. The EU's image as a significant international player (especially in the economic field) is still evident, despite the economic and financial turmoil in Europe. Intriguingly, any economic challenges are seen as being euro-based and euro-specific and, as such, a wounded European economy is seen as injured but not contagious to Asia-Pacific. However, a growing interdependence and interconnectedness of the multi-polar world suggests that such isolation and insulation may be transitory and that a weaker counterpart will have a more pervasive and negative effect. Even though the EU's ailing economy is not, as yet, seen as threatening to the wellbeing of Asia-Pacific economies, a negative attitude towards the "weak link' may prevail in the future. On the other hand, the EU's political, security, social, environmental and developmental international profiles appear to have become increasingly marginalised in Asia-Pacific perceptions of the Union. 'Soft' normative power Europe is not widely recognised in the news media or public and elites in the region suggesting, perhaps, that the Lisbon effect has 
been overshadowed by the eurozone crisis, and the repercussions for the image of the EU in the formative years of the EEAS are of a major negative character.

The guest editors of this issue (who are also the research leaders of the project 'The EU in the Eyes of Asia Pacific') would like to express their sincere gratitude to the editorial team of Tallinn University of Technology-based BJES and the team of researchers who were essential for the successful completion of the project (Aksel Kirch, Peeter Müürsepp, Kait Tamm, Tarmo Tuisk, Piret Frey, Eleonora de Crescenzo, Felicity Hattrell, Jana Lesmann, and Vlad Vernygora). We also would like to express our immense gratitude to the Jean Monnet Programme, Directorate General Education and Culture, European Commission, and Intellectual Exchange Programme of Asia Europe Foundation (ASEF), Singapore - their high evaluation and continuous support made an ambitious research idea a reality.

Dr. Natalia Chaban is Associate Professor and Jean Monnet Chair in European Identity and Culture and Deputy Director of the National Centre for Research on Europe at the University of Canterbury, NZ. She is a member of NZ-EU Centres Network Executive Board since 2006 and a co-editor of a peer-reviewed Australian and New Zealand Journal of European Studies since its inception in 2009. She teaches and designs a variety of under- and post-graduate courses and supervises MA and PhD students in EU Studies. Dr. Chaban has significant experience in analysing EU identity outside the EU, widely publishing and advancing methodological training in this regard. Since 2002, she has led a comparative transnational project on EU external perceptions comprising a multicultural team from twenty Asia-Pacific EU locations. She is a co-leader of a 'mirror'-perceptions study 'Asia in Eyes of Europe' leading a consortium of researchers from eight Member States of the EU. Among her publications is The European Union and the Asia-Pacific: Media, Public and Elite Perceptions of the EU (2008, Routledge, co-edited with M. Holland). She has also published articles in journals such as European Foreign Affairs Review, The Journal of Common Market Studies, Journal of European Integration, European Law Journal, Mobilities, and International Journal of Intercultural Relations.

Professor Martin Holland has an established reputation for both academic excellence in EU Studies (as a former Jean Monnet Chair and ad personam Chair holder) and for innovative ideas and the capacity to deliver. For over 25 years Professor Holland has been a leading academic commentator on the evolution of the EU's foreign and development policies and sits on a number of Boards for regional EU Studies Centres and Associations. $\mathrm{He}$ is the author and co-author of 21 books, teaches at undergraduate and graduate level and supervises over 20 thesis students. In 2000, Professor Holland established the National Centre for Research on Europe at the University of Canterbury. He was also instrumental in setting up the NZ European Union Centres Network (EUCN), bringing together all eight universities in New Zealand aimed at promoting EU studies, for which he is now Director. As EUCN's Director he oversees the development of school curriculum resources for New Zealand secondary school teachers. 


\section{References}

Boulding, K. (1969), 'National image and international systems,' in J. N. Rosenau (ed.) International Politics and Foreign Policy: A reader in research and theory, New York: Free Press, pp. 422-431.

Bretherton, C. \& Vogler, J. (1999), The European Union as a Global Actor, London \& New York: Routledge. http://dx.doi.org/10.4324/9780203196076

Castano, E.; Sacchi, S. \& Gries, P. H. (2003), 'The Perception of the Other in International Relations: Evidence for the Polarizing Effect of Entitativity,' Political Psychology, vol. 24, no. 3, pp. 449-468.

http://dx.doi.org/10.1111/0162-895X.00336

Chaban, N. \& Holland, M., eds. (2008), The European Union and the Asia-Pacific: Media, Public and Elite Perceptions of the EU, London \& New York: Routledge.

Chaban, N.; Holland, M. \& Ryan, P., eds. (2009), The EU through the Eyes of Asia: New Cases, New Findings, Singapore \& London: World Scientific.

EEAS (n.d.), Asia, European External Action Service website. Retrieved from http:// eeas.europa.eu/asia/index_en.htm [accessed 10 Dec 2011]

Holland, M. \& Chaban, N., eds. (2010), Reflections from Asia and Europe: How do we perceive one another? Special Issue of Asia Europe Journal, vol. 8, no. 2.

Holland, M. et al., eds. (2007), The EU through the Eyes of Asia, Warsaw \& Singapore: University of Warsaw.

Islam, S. (2010), “A seat for the EU at East Asia's top table," EUobserver, 11 November 2010. Retrieved from http://euobserver.com/9/31241 [accessed 14 Nov 2010] (2012), "On the need for Europe to learn from Asia and the ineffective use of the EU's 'soft power'," Interview with Shada Islam, conducted by J. Janda, Global Europe, 13 July 2012. Retrieved from http://www.global-europe.org/detailarticles.php?articles $=0000000035$ [accessed 13 Jul 2012]

Kirch, A. \& Tuisk, T. (2013), 'On the Profile of the Baltic Journal of European Studies (BJES),' Baltic Journal of European Studies, vol. 3, no. 1, pp. 2-5. http://dx.doi.org/10.2478/bjes-2013-0001

Renard, T. \& Biscop, S. (2012), The European Union and Emerging Powers in the $21^{\text {st }}$ Century: How Europe Can Shape a New Global Order, Farnham: Ashgate.

Renard, T. \& Struye de Swielande, T. (2011), Geopolitics and Geostrategy in the Asia-Pacific Region: Europe as Actor or Spectator? Special issue of Studie Diplomatica, vol. 64, no. 3.

Tsuruoka, M. (2011), "Defining Europe's Strategic Interests in Asia," Studie Diplomatica, vol. 64, no. 3, pp. 95-107. 